Keller, R., Smith, P. F. \& Morton, H. E. (1952). J. gen. Microbiol. 7, 313-319.

\title{
Susceptibility of Pleuropneumonia-like Organisms from Human Genital Tract to the Action of Soaps
}

\author{
By R. KELLER, P. F. SMITH, $* \dagger$ and H. E. MORTON
}

Department of Microbiology, School of Medicine, University of Pennsylvania, and the Institute for the Study of Venereal Diseases, University of Pennsylvania, cooperating with the United States Public Health Service, Philadelphia 4, Pennsylvania

SUMMARY: Pleuropneumonia-like organisms (PPLO) of human origin are very susceptible to the deleterious action of soaps. There was no significant difference in the antibacterial action of soaps containing $2 \%$ hexachlorophene and an ordinary hand soap, on the pleuropneumonia-like organisms tested. The great susceptibility of these organisms to soap probably masks any action which the hexachlorophene contained in the medicated soaps might have on PPLO. The deleterious action of soaps on pleuropneumonia-like organisms is bactericidal.

The fragility of pleuropneumonia-like organisms (PPLO) from man and the L-forms of bacteria has been stressed for many years by Dienes and summarized in his recent review (Dienes \& Weinberger, 1951). The best information concerning the nature of a cell wall or bordering membrane has been contributed by studies with the electron microscope as the small size of these organisms does not permit good cytological studies with the light microscope.

From electron microscope studies of bovine pleuropneumonia organisms and Seiffert's saprophytic organisms, Ruska \& Poppe (1948) concluded that the bordering substance of the organisms should be considered as a plasmalemma rather than as a cell wall as encountered in bacteria. The covering substance does not seem to be different from the inner substance. It has a strong attachment to the inner substance, is plastic and changeable in form. The authors were unable to coagulate and remove the cytoplasm from the cell membrane by means of heat as it is possible to do with bacteria.

Smith, Hillier \& Mudd (1948), in studying with the electron microscope two strains of PPLO isolated from man, observed that the round bodies and rodshaped cells were readily destroyed by immersion in distilled water, which proved that they did not possess a sturdy outer structure comparable to the cell wall of ordinary bacteria. In one strain the rod forms had a limiting structure from which the cytoplasm appeared to separate upon drying. The size, shape, and cell-wall structure led these authors to conclude that the PPLO must be regarded as indubitable bacterial cells.

Since it may be assumed that the visible elements of PPLO are probably bacterial in nature but with a cell wall more fragile than that of ordinary bacteria, it is reasonable to suppose that the organisms would be very susceptible to agents which lower the surface tension as, for example, soap. The experimental work to be described bears out this supposition.

* Difco Laboratories Fellow in Bacteriology.

$\dagger$ Present address, Merck and Co. Inc., Rahway, N.J., U.S.A.

G M VII $3 \& 4$ 


\section{EXPERIMENTAL}

\section{Cultures}

Staphylococcus aureus, the F.D.A. strain customarily used for phenol coefficient testing. It was killed in exposures of 5,10 and $15 \mathrm{~min}$. by phenol, $1: 70$, when subcultured into extract broth or into fluid thioglycollate medium but it was not killed by phenol, $1: 80$, under the same conditions.

Bacterium coli, P3, a communis strain.

Pleuropneumonia-like organisms. All were of human origin: Strain $07 \mathbf{P}$ was received from I. G. Schaub, Johns Hopkins University, in 1948. The same strain, 07 , and strain 09 were received from the same source in 1949. Strain 48 was isolated from urethral discharge, strain 60 from the cervical canal, and strains 43 and 107 were isolated by us from prostatic secretions.

\section{Media}

Extract broth had the following composition: beef extract (Difco), $0 \cdot 3 \%$, peptone (Parke-Davis), $1 \%$, and sodium chloride, $0.5 \%$. The $\mathrm{pH}$ was $\mathbf{7 \cdot 2}$ after sterilization in the autoclave.

Bacto-heart infusion broth enriched with Bacto-PPLO bovine serum fraction A, $1 \%$ (Smith \& Morton, 1951), was employed when it was necessary to grow PPLO in a liquid medium. For ascertaining growth of PPLO in liquid media it is necessary to subculture on to solid medium. For this purpose Bacto-PPLO agar (Morton, Smith \& Leberman, 1951) enriched with Bacto-PPLO bovine serum fraction A was used. All cultures were incubated aerobically at $37^{\circ}$.

\section{Soaps}

Dial soap was purchased over the counter. It is a bar soap stated to contain $2 \%$ hexachlorophene (G-11) and is manufactured by Armour and Co. Gamophen antiseptic soap was kindly supplied by Dr Herbert L. Davis, Ethicon Suture Labs. It is a bar soap stated to contain $2 \%$ hexachlorophene. Ivory soap (manufactured by Proctor and Gamble), was employed as an example of non-medicated soap for a control. Solutions of the various soaps were prepared by dissolving $1 \mathrm{~g}$. of thin shavings from the bars in sterile distilled water in a glass-stoppered graduated cylinder, usually diluting to a volume of $50 \mathrm{ml}$. The soap solutions were freshly prepared, and subsequent dilutions of soaps were prepared with sterile distilled water from these initial solutions.

\section{Methods}

For determining the antibacterial action of soaps, $5 \mathrm{ml}$. of the soap solutions were placed in sterile test-tubes, $16 \times 150 \mathrm{~mm}$. In the case of the bacterial cultures $0.5 \mathrm{ml}$. of a $24 \mathrm{hr}$. broth culture was added to each medication tube. In the case of the strains of PPLO a block of agar containing colonies of PPLO was placed in a tube of the enriched heart infusion broth and incubated for 3 days. One-half ml. amounts of these cultures were added to the medication tubes. The temperature of the medication was room temperature. 
For subculturing, $\mathbf{0 . 5} \mathrm{ml}$. portions were transferred at stated intervals from the medication tubes to the subculture medium. In the case of the bacteria the subculture medium was $10 \mathrm{ml}$. amounts of extract broth. In the case of the primary subcultures of the bacteria from the medication tubes growth was ascertained by turbidity and Gram staining. Those tubes showing no growth were kept under observation for 1 week. In the case of the PPLO the subculture medium was $5 \mathrm{ml}$. amounts of the enriched heart infusion broth. These primary subcultures of PPLO were incubated for 3 days at $37^{\circ}$ and then a loopful was streaked over the surface of the enriched PPLO agar. These cultures were incubated for 3 days and then examined for characteristic colonies by the microscope, employing a magnification of $\times 100$. This step was necessary to determine whether growth had taken place in the primary subcultures, as growth of PPLO in liquid media cannot be determined by turbidimetric or staining procedures.

Because of the low surface tension of soap solutions and the wide range in concentration of the soap solutions used, as well as the desirability of employing a large number of test organisms where bacteriostatic action is being studied, subcultures were made by transferring $0.5 \mathrm{ml}$. amounts with sterile pipettes from the medication tubes. The possible advantages of this volumetric transfer have been discussed previously (Tobie \& Orr, 1944; Tice \& Pressman, 1945; Pressman \& Rhodes, 1946; Morton, North \& Engley, 1948).

To insure that the inoculum in the subculture tubes did not contain sufficient material to exert a bacteriostatic effect in the subcultures, the following control was made. One-half $\mathrm{ml}$. of culture was added to $5 \mathrm{ml}$. of sterile distilled water. After $15 \mathrm{~min} .0 .5 \mathrm{ml}$. of the diluted culture was transferred to $10 \mathrm{ml}$. of extract broth containing $0.5 \mathrm{ml}$. of the respective soap solution.

\section{RESULTS}

The results obtained when the three bar soaps were tested against Bact. coli are summarized in Table 1 . The three soaps did not sterilize the test culture. These results are in agreement with the findings of Walker (1925) who found that a white floating soap and a perfumed toilet soap did not kill Bact. coli when using the stiffest possible lather which was determined to be about $8 \%$ with the soaps used. However, certain chemically pure soaps have a killing action on Bact. coli. Walker (1925) reported that $0.2 \mathrm{~N}$ solutions of sodium

Table 1. The effect of soaps on Bacterium coli when subcultures are made from medication tubes to extract broth

\begin{tabular}{lcccc}
\multicolumn{4}{c}{ Time of exposure } \\
Soap & $\overbrace{\text { Control }} \cdot$ & $\mathbf{5}$ min. & $10 \mathrm{~min}$. & $\mathbf{1 5} \mathrm{min}$. \\
Ivory, $1: 50$ & + & + & + & + \\
Gial, $1: 25$ & + & + & + & + \\
Gamophen, $1: 50$ & + & + & + & +
\end{tabular}

$+=$ growth of test organism.

Control $=0.5 \mathrm{ml}$. culture added to $5 \mathrm{ml}$. distilled water. After $15 \mathrm{~min} .0 .5 \mathrm{ml}$. transferred to $10 \mathrm{ml}$. extract broth containing $0.5 \mathrm{ml}$. of the respective soap solutions. 
oleate and sodium linolate had no killing action, but $0 \cdot 1 \mathrm{~N}$ solutions of sodium laurate and sodium palmitate killed. These results are comparable to the findings of Reichenbach (1908).

The results obtained when the three bar soaps were tested against Staph. aureus are summarized in Tables 2 and 3. The results with Ivory soap are comparable to those obtained earlier with other toilet and household soaps (Morton, 1944), namely, no killing action. In the case of the bacteriostatic control with Dial soap, the soap carried into the subculture medium with the inoculum did not inhibit the growth of the test organisms. However, failure to get growth in the subcultures from some of the medication tubes may have been due to the fact that the test organisms had been in intimate contact with the soap and were in a state of bacteriostasis.

Table 2. The effect of soaps on Staphylococcus aureus when subcultures are made from the medication tubes into extract broth and when subcultures from the gamophen-containing tubes are made into extract broth containing $10 \%$ serum.

Soap

Ivory, $1: 50$

Dial, $1: 500$

$1: 600$

$1: 700$

$1: 800$

Gamophen, $1: 200$

$1: 400$

$1: 800$

$1: 1200$

$1: 1600$

Gamophen, $1: 100$

$1: 200$

$1: 400$

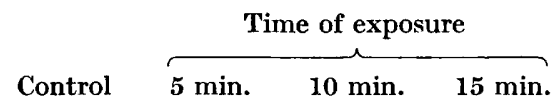

Subcultures made into extract broth

$\begin{array}{cccc}+ & + & + & + \\ + & - & - & - \\ . & - & - & - \\ . & - & - & - \\ \cdot & + & + & + \\ - & - & - & - \\ - & - & - & - \\ - & - & - & - \\ + & - & - & - \\ + & - & - & -\end{array}$

Subcultures made in extract broth plus $10 \%$ serum

$\begin{array}{llll}+ & + & + & + \\ + & + & + & + \\ + & + & + & +\end{array}$

$+=$ growth $; \quad-=$ no growth of test organism.

Control $=0.5 \mathrm{ml}$. culture added to $5 \mathrm{ml}$. distilled water. After $15 \mathrm{~min} .0 .5 \mathrm{ml}$. transferred to $10 \mathrm{ml}$. of the subculture medium containing $0.5 \mathrm{ml}$. of the respective soap solution.

It was readily apparent from the control tubes that sufficient gamophen soap was carried into the subculture with the inoculum to inhibit viable organisms which might be present in the inoculum. It was necessary, therefore, to add a substance such as serum to the subculture medium to neutralize the bacteriostatic action of the soaps. It has been known for some time that serum will decrease the bacteriostatic and lytic action of soaps (Lamar, 1911; Walker, 1924). With $10 \%$ bovine serum present in the subculture medium to neutralize the bacteriostatic action of the soaps, growth took place in all subculture tubes. 
The presence of serum or of certain fractions of serum (Edward \& Fitzgerald, 1951; Smith \& Morton, 1951) appears to be necessary for the growth of PPLO in vitro. Since whole serum is frequently inhibitory to PPLO and PPLO bovine serum fraction $\mathbf{A}$ is free of the inhibiting substances, the latter substance was used for enriching the culture medium. It was necessary, therefore, to determine whether PPLO bovine serum fraction A, like whole serum, was capable of decreasing the bacteriostatic action of soap. For this purpose $\mathbf{0 . 5} \mathrm{ml}$. of a broth culture of Staph. aureus was added to each of four dilutions of Dial soap. After $10 \mathrm{~min}$. exposure at room temperature, $0 \cdot 1 \mathrm{ml}$. of the soap + culture mixture was transferred to $(a)$ a tube of extract broth, (b) a tube of extract broth containing $10 \%$ bovine serum, and $(c)$ a tube of extract broth containing $2 \%$ PPLO bovine serum fraction $A$. The results are summarized in Table 3; it can be seen that PPLO bovine serum fraction $A$ and serum have a similar action in this respect.

Table 3. Ability of serum and PPLO bovine serum fraction $A$ to neutralize the bacteriostatic action of Dial soap on Staphylococcus aureus

$\begin{array}{cccc} & \text { Extract broth } & \begin{array}{c}\text { Extract broth } \\ +10 \% \text { serum }\end{array} & \begin{array}{c}\text { Extract broth } \\ +2 \% \text { fraction A }\end{array} \\ \text { Dial, } 1: 200 & -* & + & + \\ 1: 400 & -* & + & + \\ 1: 800 & -\dagger & + & + \\ 1: 1600 & -\dagger & + & +\end{array}$

$-=$ no growth $;+=$ growth of test organism.

* No growth obtained when one loopful of subculture was streaked on extract agar.

$\dagger$ Growth of test organism obtained when one loopful of culture was streaked on extract agar.

The results of the tests with PPLO against non-medicated and medicated soaps are given in Table 4. Because of the nature of PPLO two types of controls were run; a dilution control and a bacteriostatic control. One-half $\mathrm{ml}$. of culture of PPLO was added to $5 \mathrm{ml}$. of sterile distilled water. After $10 \mathrm{~min} .0 .5 \mathrm{ml}$. was transferred to $5 \mathrm{ml}$. of liquid medium for the dilution control. After these subcultures were incubated for 3 days, one loopful from each was streaked on solid medium. In every case growth of the test organism took place. After the $10 \mathrm{~min}$. exposure to distilled water $0.5 \mathrm{ml}$. of the diluted culture was transferred to $5 \mathrm{ml}$. of liquid medium containing $0.5 \mathrm{ml}$. of $1: 1000$ dilution of the respective soap for a bacteriostasis control. After these subcultures were incubated for 3 days, one loopful from each was streaked on solid medium. In the majority of instances the test organism grew. The results of this control are incorporated in Table 4.

\section{DISCUSSION}

The presence of serum or a fraction of serum in the culture medium necessary for the growth of PPLO also neutralizes the bacteriostatic action of soap and hexachlorophene. Failure to get growth of these organisms in the subcultures indicated that the action of soaps was bactericidal. 
Table 4. The effect of soaps on pleuropneumonia-like organisms

\begin{tabular}{|c|c|c|c|c|c|c|c|}
\hline \multirow[b]{2}{*}{ Culture } & \multirow[b]{2}{*}{ Dilution } & \multicolumn{3}{|c|}{ Ivory soap } & \multicolumn{3}{|c|}{ Dial soap } \\
\hline & & Control* & 5 min. & $10 \mathrm{~min}$. & Control & $5 \mathrm{~min}$. & $10 \mathrm{~min}$. \\
\hline \multirow[t]{4}{*}{ PPLO, strain 07 $\mathrm{P}$} & $1: 1,000$ & + & - & - & + & - & - \\
\hline & $1: \mathbf{2 , 5 0 0}$ & . & - & - & . & - & - \\
\hline & $1: 5,000$ & . & + & + & - & + & + \\
\hline & $1: 10,000$ & - & + & + & - & + & + \\
\hline \multirow[t]{4}{*}{ PPLO, strain 09} & $1: 1,000$ & $+\dagger$ & - & - & + & - & - \\
\hline & $1: 2,500$ & . & - & - & . & - & - \\
\hline & $1: 5,000$ & . & - & - & . & - & - \\
\hline & $1: 10,000$ & . & + & + & . & + & + \\
\hline \multirow[t]{4}{*}{ PPLO, strain 43} & $1: 1,000$ & + & - & - & + & - & - \\
\hline & $1: 2,500$ & . & - & - & . & - & - \\
\hline & $1: 5,000$ & . & - & - & . & + & - \\
\hline & $1: 10,000$ & . & + & + & . & + & + \\
\hline \multirow{4}{*}{ PPLO, strain 07} & $1: 1,000$ & + & - & - & - & - & - \\
\hline & $1: 2,500$ & . & - & - & - & - & - \\
\hline & $1: 5,000$ & - & + & + & . & + & - \\
\hline & $1: 10,000$ & - & + & + & • & + & + \\
\hline \multirow[t]{3}{*}{ PPLO, strain 107} & $1: 2,500$ & + & . & - & - & . & - \\
\hline & $1: 5,000$ & - & . & + & . & . & . \\
\hline & $1: 10,000$ & $\cdot$ & $\cdot$ & + & - & - & $\cdot$ \\
\hline \multirow[t]{4}{*}{ PPLO, strain 48} & $1: 1,000$ & - & - & - & \pm & - & - \\
\hline & $1: 2,500$ & . & - & - & . & - & - \\
\hline & $1: 5,000$ & . & - & - & . & - & - \\
\hline & $1: 10,000$ & $\cdot$ & + & + & - & + & + \\
\hline \multirow[t]{4}{*}{ PPLO, strain 60} & $1: 1,000$ & \pm & - & - & + & - & - \\
\hline & $1: 2,500$ & . & - & - & - & - & - \\
\hline & $1: 5,000$ & - & + & + & - & - & - \\
\hline & $1: 10,000$ & . & + & + & . & + & - \\
\hline
\end{tabular}

$-=$ no growth in subcultures; $+=$ growth in subcultures; $\pm=$ growth in one experiment, no growth in another experiment.

* Control for bacteriostasis: $0.5 \mathrm{ml}$. culture added to $5 \mathrm{ml}$. distilled water. After $10 \mathrm{~min}$. (a) $0.5 \mathrm{ml}$. transferred to $5 \mathrm{ml}$. liquid culture medium containing $0.5 \mathrm{ml}$. $1: 1,000$ dilution of the respective soaps; $(b) 0.5 \mathrm{ml}$. transferred to $5 \mathrm{ml}$. liquid medium. After incubation for 3 days one loopful from each tube was streaked on solid medium to determine if growth of the organisms had taken place. In every case the dilution controls $(b)$ were positive. The results of $(a)$ the bacteriostasis controls are given in the table.

$\dagger$ Culture contaminated with bacteria.

It has been found that Haemophilus influenzae, Streptococcus pneumoniae (Nichols, 1920), Corynebacterium diphtheriae (Walker, 1925), Neisseria meningitidis, $N$. gonorrhoeae (Walker, 1926), and Treponema pallidum (Reasoner, 1917) are readily destroyed by ordinary soaps. Strep. pyogenes (Nichols, 1920; Walker, 1931) and Salmonella typhi (Walker, 1925) are also destroyed by soaps but less readily.

The susceptibility of PPLO to the action of soaps is much greater than that of the highly susceptible bacteria. It is interesting to note that Warren (1942) observed that the susceptibility of pleuropneumonia organisms and certain L-forms to hydrogen peroxide, phenol, and ultraviolet light was of the same magnitude as that of some of the ordinary bacteria. The unusually high susceptibility of PPLO to soaps is probably due to the fact that the organisms possess a very fragile cell structure. 


\section{REFERENCES}

Dienes, L. \& Weinberger, H. J. (1951). The L-forms of bacteria. Bact. Rev. 15, 245.

Edward, D. G. FF. \& Fitzgerald, W. A. (1951). Cholesterol in the growth of organisms of the pleuropneumonia group. J. gen. Microbiol. 5, 576.

Lamar, R. V. (1911). Chemo-immunological studies on localized infections. Second paper: Lysis of the pneumococcus and hemolysis by certain fatty acids and their alkali soaps. J. exp. Med. 13, 380.

Morton, H. E. (1944). 'Germicidal' soaps. I. The importance of a clean skin, the action of soaps in freeing the skin of viable microorganisms, and methods for testing the efficiency of germicidal (medicated) soaps. J. Amer. med. Ass. $124,1195$.

Morton, H. E., North, L. L. \& Engley Jr., F. B. (1948). The bacteriostatic and bactericidal actions of some mercurial compounds on hemolytic streptococci. J. Amer. med. Ass. 136, 36.

Morton, H. E., Smith, P. F. \& Leberman, P. R. (1951). The cultivation of pleuropneumonia-like organisms from the human genitourinary tract with reference to their possible venereal transmission. Amer. J. Syph. 35, 14.

NichoLs, H. J. (1920). Bacteriologic data on the epidemiology of respiratory diseases in the Army. J. Lab. clin. med. 5, 502.

Pressman, R. \& Rhodes, J. C. (1946). Sources of error in germicidal activity tests with quaternary ammonium compounds. Soap sanit. Chemicals, 22, 137, 139, $141,143$.

Reasoner, M. A. (1917). The effect of soap on Treponema pallidum. J. Amer. med. Ass. 68, 973.

Reichenbach, H. (1908). Die desinfizierenden Bestandteile der Seifen. Z. Hyg. InfektKr. 59, 296.

Ruska, H. \& Poppe, K. (1948). Elektronenmikroskopische Untersuchungen zur Morphologie der Seiffertschen Mikroorganismen und des Erregers der Lungensuche des Rindes. Z. Hyg. InfektKr. 127, 201.

Smith, P. F. \& Morton, H. E. (1951). The separation and characterization of the growth factor in serum and ascitic fluid which is required by certain pleuropneumonia-like organisms. J. Bact. 61, 395.

Smith, W. E., Hillier, J. \& Mudd, S. (1948). Electron micrograph studies of two strains of pleuropneumonia-like (L) organisms of human derivation. J. Bact. $56,589$.

Tice, L. F. \& Pressman, R. (1945). Antiseptics of the quaternary ammonium type in the presence of positive and negative gelatin. J. Amer. pharm. Ass. (scientific ed.), 34, 201.

TobIe, W. C. \& ORR, M. L. (1944). Determination of phenol coefficients in presence of surface tension depressants. J. Lab. clin. Med. 29, 767.

WALKER, J. E. (1924). The germicidal properties of chemically pure soaps. J. infect. Dis. 35, 557.

WALKER, J. E. (1925). The germicidal properties of soap. J. infect. Dis. 37, 181.

Walker, J. E. (1926). The germicidal properties of soap. J. infect. Dis. 38, 127.

WALker, J. E. (1931). The germicidal and therapeutic applications of soaps. J. Amer. med. Ass. 97, 19.

WARREN, J. (1942). Observations on some biological characteristics of organisms of the pleuropneumonia group. J. Bact. 43, 211.

(Received 28 March 1952) 